\title{
Effect of the thermal gradient variation through geological time on basin modeling; a case study: The Paris basin
}

\author{
L. Amir ${ }^{\mathrm{a}}$, L. Martinez ${ }^{\mathrm{a}}{ }^{\prime}$, , J.R. Disnar ${ }^{\mathrm{b}}$, J.-L. Vigneresse ${ }^{\mathrm{a}}$, R. Michels ${ }^{\mathrm{a}}{ }^{,}$, F. Guillocheau ${ }^{\mathrm{c}}$ \\ and C. Robin ${ }^{\mathrm{d}}$ \\ ${ }^{a}$ G2R-UMR 7566/CNRS, Université Henri Poincaré, Nancy, France \\ ${ }^{\mathrm{b}}$ ISTO, UMR CNRS 6113, Géosciences, Université d'Orléans, BP 6759, 45067 Orléans cedex \\ 2, France \\ ${ }^{c}$ UPR-4661, Géosciences Rennes, Université de Rennes I, France \\ ${ }^{d}$ ESA-7073, Paléontologie et stratigraphie, Université Pierre et Marie Curie, Paris, France
}

\begin{abstract}
Many studies investigated the thermal modeling of the Paris basin for petroleum interests during the 1970s. Most of the softwares developed by oil companies or research centers were based on the assumption of a constant thermal gradient. In order to take into consideration the variation of the thermal gradient during basin evolution, we developed the TherMO's Visual Basic 1D program. We applied our model to twenty boreholes located along a cross-section roughly running EW over $150 \mathrm{~km}$ in the center of the Paris basin. The numerical results were calibrated with organic matter maturity data. TherMO's simulates the amount of heat provided to the sedimentary organic matter. The heat parameter simulated shows lateral variation along the cross-section. It decreases from Rambouillet to Trou Aux Loups boreholes (87-66 $\mathrm{mW} / \mathrm{m}^{2}$ ) at about $100 \mathrm{~km}$ more to the east whereas the heat flux value simulated is $73 \mathrm{~mW} / \mathrm{m}^{2}$ in St. Loup borehole. The mean thermal gradient calculated for liassic horizons at $87 \mathrm{My}$ for the Rambouillet well is $50.4{ }^{\circ} \mathrm{C} / \mathrm{km}$. This value is similar to previously published results. By integrating the calculation of the thermal gradients and conductivities related to the burial of each stratigraphic sequence, our approach points out variations in the thermal regimes the sedimentary organic matter (SOM) has been subjected to through geological time.
\end{abstract}

Keywords: Paris basin; Thermal modeling; Sequence stratigraphy; Sedimentary organic matter; Basinal heat flux

\section{Introduction}

Thermal modeling in sedimentary basins helps determining the location of oil and/or gas generative formations, and additionally the timing of hydrocarbon generation (Yukler and Kokesh, 1984). In addition to the quality of the input data, the reliability of the output information also depends on the modeling resolution scale.

The Paris basin has for long been widely studied by the oil industry and academic research both as an effective exploration target and a convenient area for checking new approaches. As a matter of fact, the modeling of its thermal (Espitalie et al., 1987) and subsidence history (Brunet and Le Pichon, 1982) gave information on petroleum generated from the lower Toarcian black shales well known as source rocks for oil (Poulet and Espitalie, 1987, Bessereau et al., 1995, Disnar et al., 1996a and Disnar et al., 1996b). Taking into account present day thermal gradients and present day thermal conductivities, modeling approaches provided thermal data such as heat flux values and palaeotemperatures. In such a way Gaulier 
and Burrus (1994) reported present day thermal gradients values around $55-65^{\circ} \mathrm{C} / \mathrm{km}$ for Liassic series. They also noticed that those values were higher than those used to describe the thermicity of the Dogger formation that is presently characterized by hot water circulations. In a more general way, the results of clay mineralogy studies suggest that thermal conditions have varied during the Paris basin history (Liewig et al., 1987 and Guilhaumou and Gaulier, 1991).

All along their formation and evolution, sedimentary basins are submitted to burial at a rate that depends on the geologic framework and on geodynamics. During burial, depositional sequences are submitted to increasing Pressure-Temperature conditions. As a consequence, the temperature and the energy provided to the sedimentary organic matter contained in the considered formations increase, thus causing kerogen thermal transformation and subsequent hydrocarbon generation.

In the present paper, we present an attempt at taking into account temporal variation of the thermal gradients and thermal conductivities in 1D modeling in a series of locations determining a cross-section in the Paris basin. In that aim, instead of approaching the thermal history through the reconstruction of the burial of a pile of sedimentary layers, we suggest integrating the stratigraphic analysis operated at a temporal resolution scale around 1-5 My during calculations. The resolution scale allows to consider minor and major transgressiveregressive cycles that occurred throughout the Paris Basin evolution (Guillocheau et al., 2000).

In a first time our model named TherMO's calculates palaeodepths and the corresponding palaeoporosity and thermal palaeoconductivity for all the stratigraphic horizons studied. In a second part it estimates the thermal parameters, calibrated against the actual maturity state of the organic matter using Rock-Eval and a kinetic model. The principles of development of the TherMO's program are described in this paper. It is applied to a cross-section in an E-W profile, along the long axis of the basin. It involves 20 boreholes (see Fig. 1) and runs from the Rambouillet reference well to a 150-km east where the St. Loup well.

\section{Geodynamic and stratigraphic framework}

The Paris Basin, initiated during the Permo-Triassic (Megnien, 1980, Brunet and Le Pichon, 1982, Curnelle and Dubois, 1986, [4] and Bourquin et al., 2002). From that time, it experienced several episodes of subsidence from Jurassic to Tertiary, mostly marked in its center, followed by uplift of its northern and southern rims during Neogene times. The major sedimentary cycles identified in the Paris Basin (first order cycles) document the geodynamic events related to the Tethys evolution to the South and the opening of the North Atlantic to the West (Guillocheau, 1991). Acceleration in the subsidence rate is marked by transgressive phases, whereas slower subsidence corresponds to regressive phases 
A
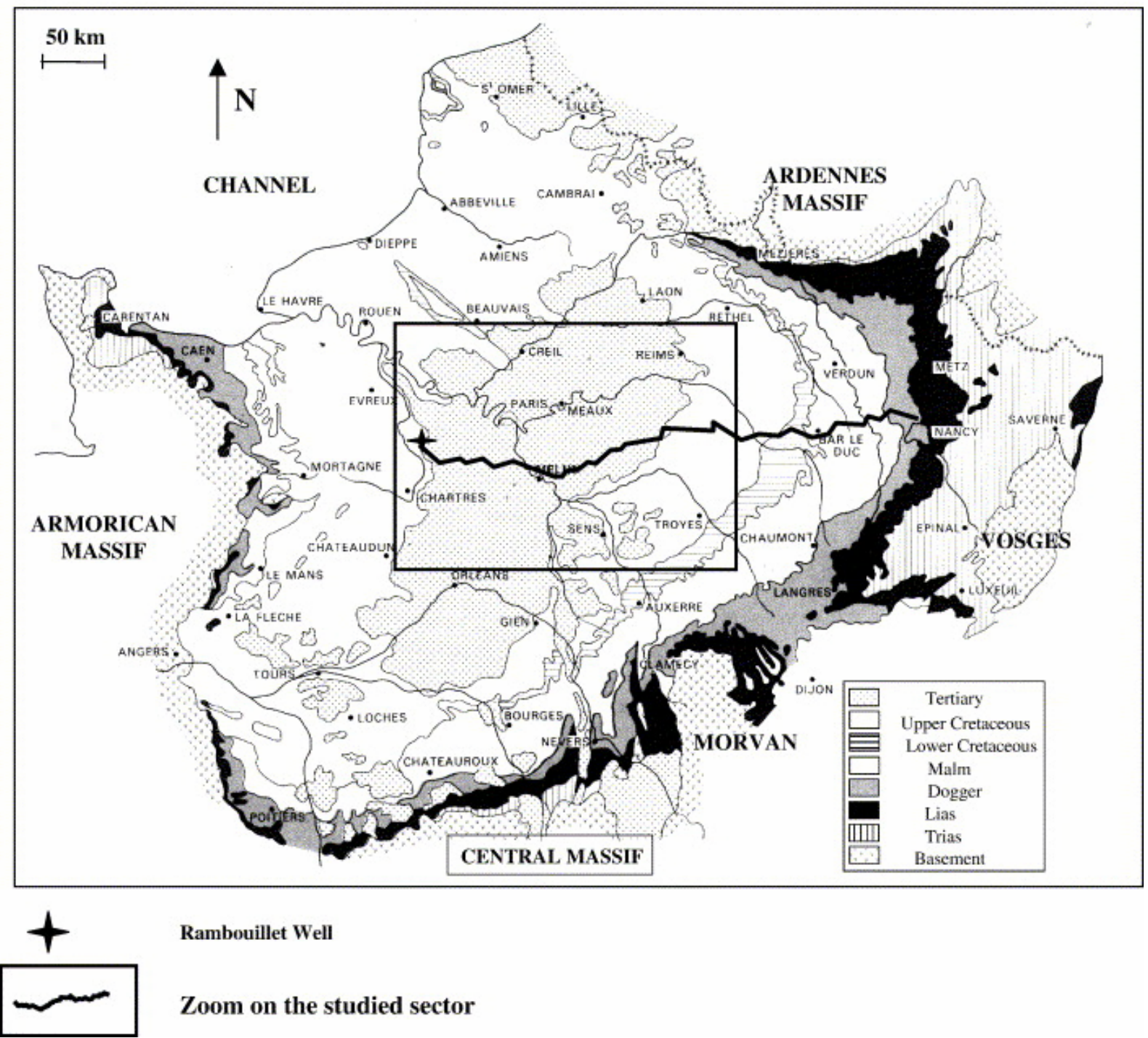

Rambouillet Well

Zoom on the studied sector 
A
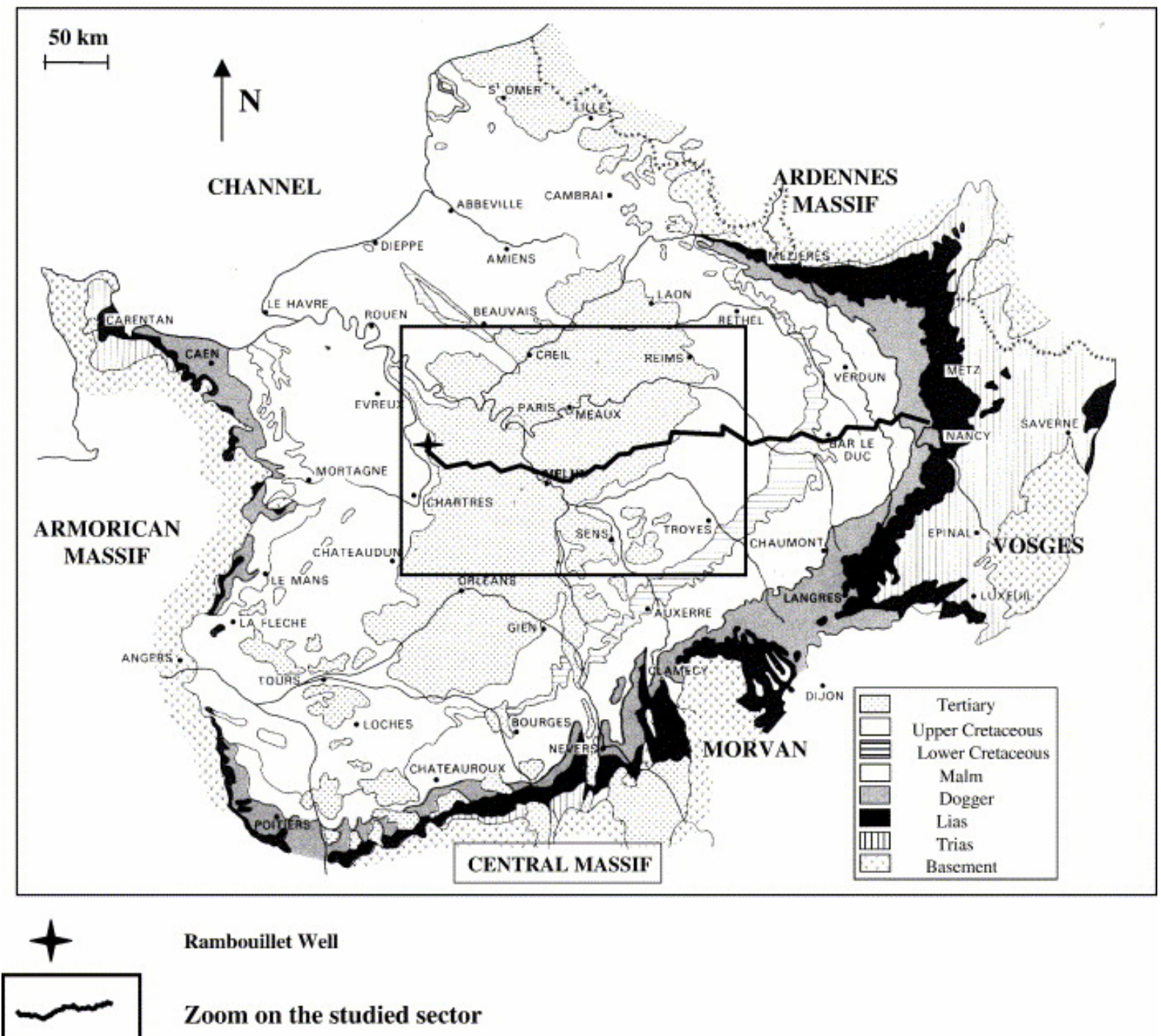

Rambouillet Well

\section{Zoom on the studied sector}

Fig. 1. (A) Geological map of the Paris Basin (from Demars, 1994). (B) Zoom on the studied section. Letters A to $\mathrm{T}$ represent the studied boreholes. Dotted lines correspond to faults identified in the Paris Basin. (FS = "Seine fault"; FB = "Bray Fault"; AC = "Chaunoy Accident"; Fsy = "Sennely Fault"; FSMB = "St Martin de Bossenay Fault").

\section{Methodology}

Throughout its history, a sedimentary basin is submitted to burial which can vary accordingly to the rate of sediments deposition and tectonic context. To reconstruct the thermal history of sedimentary basins, the burial history for each stratigraphic sequence is first determined. Then, the thermal parameters are computed by taking into account the burial parameters of each stratigraphic sequence (Fig. 2). 


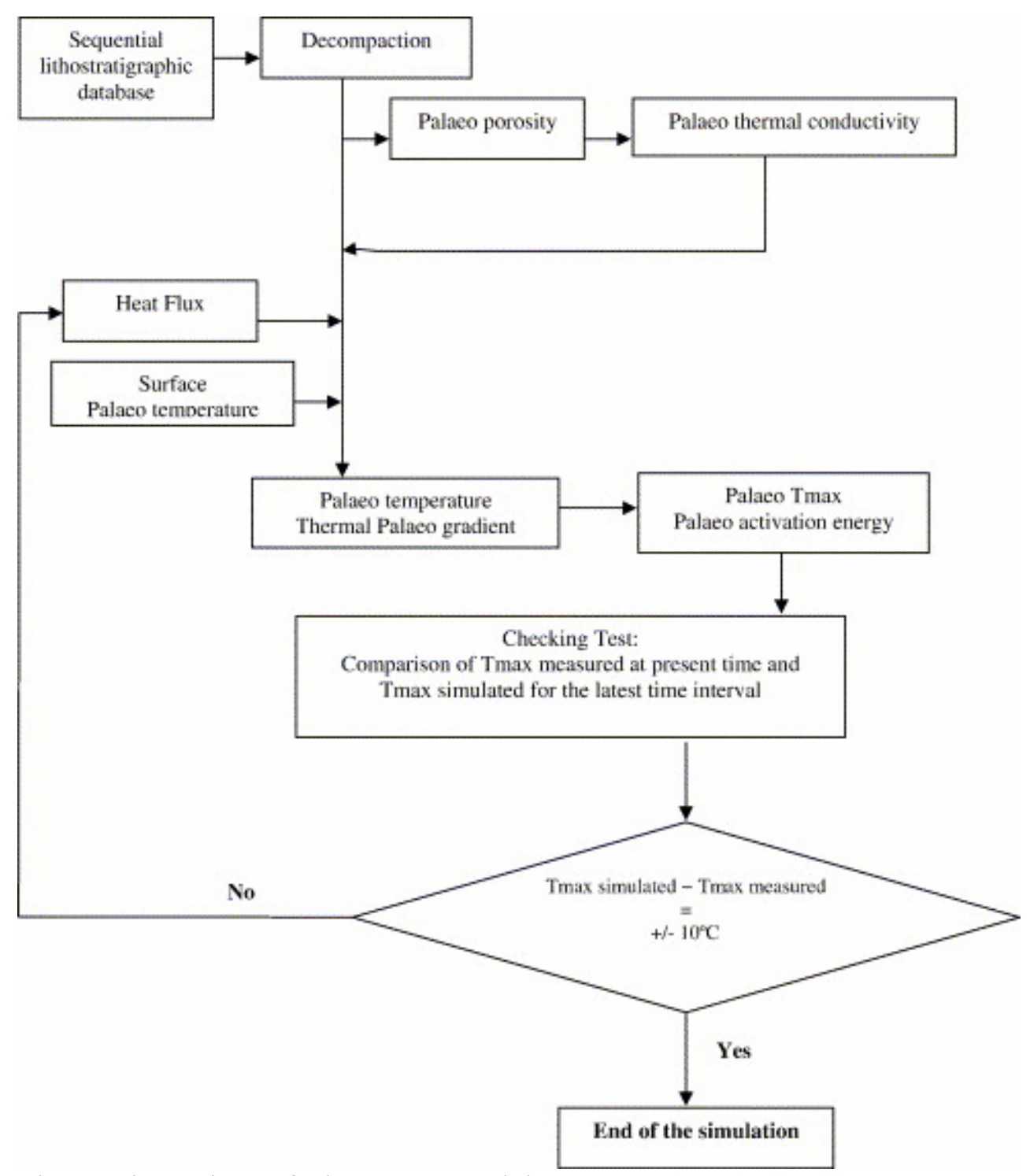

Fig. 2. Flow Chart of TherMO'S model.

\subsection{Burial history of sedimentary basins: burial procedure}

\subsubsection{Palaeodepth}

The TherMO's program includes the classical methods used for solving the problem of sedimentary units submitted to compaction and decompaction (Brunet and Le Pichon, 1980 and Allen and Allen, 1990). The code was written by considering the empirical law which links porosity to depth. The surface porosity and the coefficient porosity parameters used in the present work are listed in Table 1. The mathematical equation for determining burial history is: 


$$
\begin{aligned}
v_{j 2}^{\prime} y_{j 1}^{\prime}= & y_{j 2}-y_{j 1}-\phi_{0 j} \frac{e^{-c_{j} y_{j 1}}-e^{-c_{j} y_{j 2}}}{c_{j}} \\
& +\phi_{0 j} \frac{e^{c_{j} y_{j 1}^{\prime}}-e^{-c_{j} y_{j 2}^{\prime}}}{c_{j}}+\text { eust }+ \text { bathy }_{j}
\end{aligned}
$$

Where: $y_{j 1}{ }^{\prime}, y_{j 2}{ }^{\prime}$ : newpalaeodepth (base and top of the sequence j); $y_{j 1}, y_{j 2}$ :present depth of the sequence $j ; \phi_{0 j}$ : surface porosity; $c_{j}$ : porosity coefficient; eust: eustatic value; bathy : $_{j}$ bathymetric correction for the sequence $j$.

\section{Table 1.}

Main numerical constants used for the modeling procedures (surface porosity, etc.) (Martinez et al., 2000;

\begin{tabular}{|c|c|c|c|c|}
\hline Lithology & $\begin{array}{l}\text { Surface porosity } \Phi_{0} \\
(\%)\end{array}$ & $\begin{array}{l}\text { Lithologic constant } \\
\left(\mathrm{km}^{-1}\right)\end{array}$ & $\begin{array}{l}\text { Depth } \\
(\mathbf{k m})\end{array}$ & $\begin{array}{l}\text { Density } \\
\left(\mathbf{k g} / \mathrm{m}^{3}\right)\end{array} \quad \rho$ \\
\hline \multirow[t]{2}{*}{ Shale 1} & 77 & 2.5 & $z<0.3$ & 2720 \\
\hline & 40 & 0.3 & $z>0.3$ & \\
\hline Shale 2 & 38 & 0.2 & $0<z<6$ & 2720 \\
\hline Silt & 49 & 0.3 & $z<6$ & 2650 \\
\hline Chalk & 71 & 0.7 & $0<z<6$ & 2710 \\
\hline \multirow[t]{2}{*}{ Limestone } & 80 & 0.5 & $z<0.5$ & 2710 \\
\hline & 50 & 0.5 & $z>0.5$ & 2710 \\
\hline Halite & 20 & 1 & $0<z<6$ & 2160 \\
\hline $\begin{array}{l}\text { Gypsum } \\
\text { anhydrite }\end{array}$ & 60 & 1 & $0<z<6$ & 2920 \\
\hline Sandstone & 49 & 0.3 & $0<z<6$ & 2650 \\
\hline Shaly sandstone & 56 & 0.4 & $0<z<6$ & 2680 \\
\hline
\end{tabular}
Durand, M., personnal communication)

\subsubsection{Palaeo porosity}

In order to estimate new palaeoporosity values which are a function of the new palaeodepths, we introduced the following expression in the subsidence procedure (Allen and Allen, 1990): 


$$
p_{j}^{\prime}=\phi_{0 j} \frac{e^{-c_{j} y_{j 1}^{\prime}}-e^{-c_{j} y_{j 2}^{\prime}}}{c_{j}\left(y_{j 2}^{\prime}-y_{j 1}^{\prime}\right)}
$$

Where $\Phi_{j}^{\prime}$ is the new paleoporosity for the sequence $j$.

\subsubsection{Thermal palaeo conductivity}

We use the geometric mean model (Vasseur et al., 1995) where the bulk conductivity is defined by:

$$
K=\prod_{j=1}^{n} K_{i j}^{\left(1-P_{i}\right)} \times 0.6^{P_{i}}
$$

where $K_{i j}$ is the experimental thermal conductivity of the $j$ th lithologic component for the considered sequence $i, P_{i}$ is the paleoporosity of the considered sequence $i$ estimated from the Eq. (2). A value of $0.6 \mathrm{~W} / \mathrm{m} / \mathrm{K}$ is taken for the thermal conductivity of water.

\subsection{The modeling of the thermal parameters}

Thermal transformations operating on organic or inorganic matter depend on the heat accumulated in each stratigraphic sequence. In each sequence the heating of the sedimentary organic matter is controlled by the temporal variation of the temperature difference between its top and base. The heat is provided to a genetic unit within a specific period of time. The sedimentary organic matter (SOM) involved in each genetic sequence is then transformed thanks to the Pressure-Temperature conditions varying all along the burial of the basin. In the present work, we do not distinguish the respective part of convection versus conduction during heat transport and the generation of heat due to radioactive disintegration. The aim of our approach is to estimate the amount of heating necessary for thermal cracking of the SOM.

\subsubsection{Computing the amount of heating}

The model supposes that thermal conductivity and thickness vary from one sequence to another according to the burial history parameters simulated at the stratigraphic resolution scale. The temperature difference between top and base of each stratigraphic sequence is estimated from the Fourier's law:

$$
\mathrm{d} T(t, s)=Q^{*} \frac{\text { thickness }(t, s)}{K(t, s)}
$$

$\mathrm{n}$ which: $\mathrm{d} T(t, s)$ is the difference of temperature between the top and the base of the considered sequence $s$ at time $t$, expressed in ${ }^{\circ} \mathrm{C} . K(t, s)$ is the thermal conductivity of the considered sequence $s$ at time $t$, expressed in $\mathrm{W} / \mathrm{m} /{ }^{\circ} \mathrm{C}$. $Q$ is the heat flux. It represents the heat provided and transfered to the sedimentary organic matter by means of the thermal 
conductivity. A numerical value is manually introduced by the user and is the same for the whole lithologic column and constant for the studied borehole. It is expressed in $\mathrm{mW} / \mathrm{m}^{2}$.

\subsubsection{Calculation of the paleotemperatures and thermal paleogradients}

The main assumptions for estimating the palaeotemperatures are the knowledge of the surface palaeotemperatures and the calculation of the temperature difference. Paleotemperatures are deduced from the following equation:

\section{$\underline{\mathrm{T}} \operatorname{bottom}(t, s)=\mathrm{T}$ top $(t, s)+\mathrm{d} T(t, s)$}

Where $\mathrm{d} T(t, s)$ is the temperature difference calculated from Eq. (4). T_bottom $(t, s)$, T_top $(t, s)$ are the temperatures $\left(\right.$ in ${ }^{\circ} \mathrm{C}$ ) simulated at the bottom and the top of the sequence $s$ at time $t$.

On the first step of the calculation, the top of the lithologic column corresponds to the surface palaeotemperature. Temperature of the bottom of the sommital sequence can then be easily deduced. Then, based on the simple assumption that the temperature of the base of a sequence is equal to the temperature of the top of the preceeding sequence, the model estimates progressively the temperature at each interface until the base of the lithologic column considered. Thermal palaeogradients are deduced from the temperature difference using the following formula:

$$
\Theta(t, s)=\frac{\mathrm{d} T(t, s)}{\operatorname{thickness}(t, s)}
$$

\subsubsection{Calibration of the modeling}

In order to control the thermal parameters simulated by TherMO's, we introduced a code based on the thermal cracking of organic matter. Basically, like other models of that kind, this latter one is based on the classical Arrhenius' empirical law (Arrhenius, 1909) which relates the rate of a reaction at a given temperature to concentrations factors, through the amount of energy required for the reaction to proceed. In fact this amount of energy is defined as the activation energy. The Arrhenius equation formulates as follows:

\section{$\underline{k=A \times \exp (-\mathrm{Ea} / R \times T)}$}

where $k$ is the rate coefficient, $A$ is the Arrhenius constant, Ea is the activation energy, $R$ is the universal gas constant, and $T$ is the temperature (in $\mathrm{K}$ ).

The maturation of the organic matter is an irreversible process which, can be reproduced experimentally by Rock-Eval pyrolysis (Disnar, 1986, Disnar, 1994 and Lafargue et al., 1998). From the single Arrhenius equation, a model was developed aiming to the determination of maximum paleotemperatures of burial from organic matter experimental data (Disnar, 1986 and Disnar, 1994). This model supposes that programmed laboratory 
pyrolysis continues the successive elimination of kerogen molecules where it had stopped during previous burial diagenesis. The experimental temperature $T_{\min }$, graphically determined at the onset of the $\mathrm{S}_{2}$ Rock-Eval pyrolysis peak, is used to calculate the corresponding maximum paleotemperatures of burial, taking into account different values of the experimental and natural thermal gradients. This calculation is operated with the following equation directly derived from the Arrhenius' law:

$$
\frac{1}{T_{2}}=\frac{R}{\mathrm{Ea}}\left(2 \ln \frac{T_{2}}{T_{1}}-\ln \frac{B_{2}}{B_{1}}\right)+\frac{1}{T_{1}}
$$

where $T_{1}$ is the experimental temperature (in $\mathrm{K}$ ), $B_{1}$ is the experimental gradient (heating rate of the Rock-Eval pyrolysis expressed in $\left.{ }^{\circ} \mathrm{C} / \mathrm{min}\right), T_{2}$ is the maximum paleotemperature of burial (in $\mathrm{K}$ ) and $B_{2}$ is the natural gradient $\left({ }^{\circ} \mathrm{C} / \mathrm{My}\right)$. In this model, the natural gradient is the product of the rate of subsidence calculated from the burial history with the mean present thermal gradient.

We consider Eq. (8) for calibration of the TherMO's model. For that purpose, the paleotemperatures and the thermal paleogradients calculated previously (see Section 3.2.2) were here transferred as known variables in order to deduce simultaneously the energies necessary for the thermal cracking of the sedimentary organic matter and the temperature for the Rock-Eval pyrolysis. Then, the analytical temperatures estimated from the modeling for the present time are compared with values effectively measured on cores samples by RockEval pyrolysis. The assumed heat parameter is manually adjusted by the user until the following condition is reached for each studied stratigraphic sequence:

$$
\left|T_{\text {simulated }}-T_{\text {measured }}\right|=0+/-10{ }^{\circ} \mathrm{C}
$$

\section{Data used in this study}

\subsection{Stratigraphic data}

The different wavelengths of tectonic movements are constrained by high-resolution 2D and 3D geometries of stratigraphic cycles. The respective lithology and facies observed within those periods also control the nature, geometry and hierarchy of the stratigraphic cycles (Guillocheau et al., 2000). The provided stratigraphic database was established in the framework of a previous scientific program (Robin et al., 1996, Robin, 1997 and Guillocheau et al., 2000). The approach used classically took into account:

(1) The identification of sequence stratigraphic isochrones (maximum flooding surfaces for instance) on diagraphic records.

(2) The biochronostratigraphic data (ammonites zones) reported in the literature; each isochron being dated with the help of Odin (1994) datation scale. For example, the isochron 
identified at the base of the Hettangian is a flooding surface marked by the planorbis ammonite zone. It corresponds to $205 \mathrm{My}$ in age, according to the Odin (1994) datation scale.

(3) The vertical stacking of parasequences: the recognition of the vertical facies evolution on diagraphic records leads to determine the transgressive-regressive cycles. It also permits to define genetic units (first order, second order, etc.).

(4) The correlation of the genetic units delimited by the identified isochrons from borehole to borehole, all along the cross-section.

Sequences are delimited by flooding and maximum flooding surface. Concerning the present work, they correspond to third order events in terms of sequence stratigraphy. The thickness of each sequence ranges from 5 to $20 \mathrm{~m}$ and it defines the depth resolution of our model. The corresponding time resolution ranges from 1 to $5 \mathrm{My}$. About 78 stratigraphic limits have been selected for each of the 20 selected boreholes. They delineate 49 sequences for which the mineral percentage (shale, carbonate, sand, etc.) was estimated from well log recordings (Robin et al., 1996 and Robin, 1997). The approach is based on the identification of homogeneous electrofacies. The analysis of gamma ray, resistivity and neutron logs lead to the recognition of diagraphic properties specific to lithologic components.

The upper stratigraphic limit of our model corresponds to an important erosion episode that occurred during Cretaceous time (Santonien, 83-87 My). The modeling is not performed to upper levels, TherMO's being not yet able to take erosional events into account. This provides the upper time constraint. The lower limit is fixed as the Triassic (Scythian, 232.5 My) considered as the basement of the modelled series. The lithologic variation in percentage of shale content recorded by the Mesozoic sediments permitted to delimit the beginning and the end of transgressive and regressive stages. For example, for the Hettangian, a minor transgressive cycle stage was delimited by the flooding surface named $\mathrm{H} 1$ and the maximum flooding surface named $\mathrm{H} 2$. Those stratigraphic horizons are respectively characterized by $30 \%$ and $80 \%$ of shales in the Rambouillet well (Robin, 1997).

\subsection{Organic matter data}

The experimental temperatures $T_{\min }$ and $T_{\max }$ correspond to different points of the pyrolysis $\mathrm{S}_{2}$ signal representing the hydrocarbons generated from the experimental heating of the kerogen. $T_{\min }$ and $T_{\max }$ parameters are determined at the onset and top of the $\mathrm{S}_{2}$ curve, respectively. Both these obey to the same kinetic laws with distinct activation energies. Only the activation energies are necessarily different according to the point location on the $\mathrm{S}_{2}$ signal (Disnar, 1986, Disnar, 1994 and Lafargue et al., 1998).

The Paris Basin was a fairly shallow epicontinental basin. The depositional conditions which prevailed during Mesozoic led to the deposition of good potential source rocks (Espitalie et al., 1987 and Ungerer et al., 1991). The best source rocks are located between the Hettangian and the Bajocian. The OM that mainly originates from marine planctonic organisms (type II) was buried at sufficient depth in the centre of the basin to produce some oil (Espitalie et al., 1987). For our modeling purposes, we used $T_{\max }$ data deduced from the iso- $T_{\max }$ curves drawn by Espitalie et al. (1987) based on the analysis of a considerable set of samples, for Hettangian, Sinemurian and lower Toarcian sequences (Espitalie et al., 1987). 


\subsection{Surface paleotemperatures data}

Stable isotope geochemistry of carbonates can be used to estimate the surface paleotemperatures. In the modeling, we introduced the surface paleotemperatures determined from the isotopic analysis of $\delta^{18} \mathrm{O}$ and $\delta^{13} \mathrm{C}$ by Bowen (1966) (see Table 2).

Table 2. : Surface palaeotemperatures used for the simulation provided and extrapolated from the literature (Bowen, 1966)

\begin{tabular}{|l|l|}
\hline Time interval (My) & Surface temperature $\left({ }^{\circ} \mathrm{C}\right)$ \\
\hline 205 to 187 & 24.5 \\
\hline 187 to 180 & 25 \\
\hline 180 to 176 & 20 \\
\hline 176 to 172 & 21 \\
\hline 172 to 167 & 17 \\
\hline From 167 & 12 \\
\hline
\end{tabular}

\section{Limits of the modeling}

As a consequence of the uncertainties specific to our code and for reasons that are general to all models, the numerical values provided by TherMO's must be interpreted with caution. On one hand, results of simulation are strongly constrained by the data implemented in the model. As for the stratigraphic constraints we had to consider, we observed that the limits of the sequences can be different depending on the authors and on the way they established their stratigraphic database. The stratigraphic database used and implemented for the present work is different from the stratigraphic database established by Jacquin and Graciansky (1997) for the Paris basin. It could be interesting to compare our results to those issued from simulations operated with other stratigraphic databases established for the Paris basin. Furthermore the model is presently unable to take erosion and possible uplift into account. However, no major erosion was identified before Cretaceous in the Paris Basin.

Uncertainties for the present evaluation of the thermal parameters are also related to the fact that we do not take into account, during the calculation, the variation of heat flux through time. For example, the procedure dealing with the estimation of the heat flux should be adapted to take into account hotter regime due to rifting periods. Threats to validity of the modeling operated also come from the uncertainty of the surface paleotemperatures estimations from the stable isotopic analysis.

Consequently, the limits of the modeling concern the precision at which the calibrations (stratigraphy, lithology, geochemistry) is performed. For estimating uncertainties values, the next steps are to use other stratigraphic database and compare the results obtained. We should also integrate in the modeling surface paleotemperatures estimated from independent methods in order to check the impact of any possible error in the estimation of the thermal parameters. 


\section{Results}

The heat flux simulated in the central part of the Paris Basin shows lateral variations along the cross-section (Fig. 3). It decreases from Rambouillet to Trou Aux Loups boreholes (87-66 $\mathrm{mW} / \mathrm{m}^{2}$ ) located about $100 \mathrm{~km}$ more to the east whereas the heat flux simulated in St. Loup Borehole is higher $\left(73 \mathrm{~mW} / \mathrm{m}^{2}\right)$. The results obtained are in agreement with heat flows values determined from a previous study realised in the center part of the Paris basin with the Temispack software (Gaulier and Burrus, 1994). Those values vary laterally between 70 and $90 \mathrm{~mW} / \mathrm{m}^{2}$. Lucazeau and Vasseur (1989) also present numerical heat flow values varying from $50 \mathrm{~mW} / \mathrm{m}^{2}$ on the western side of the Paris Basin to about $80 \mathrm{~mW} / \mathrm{m}^{2}$ in the center.
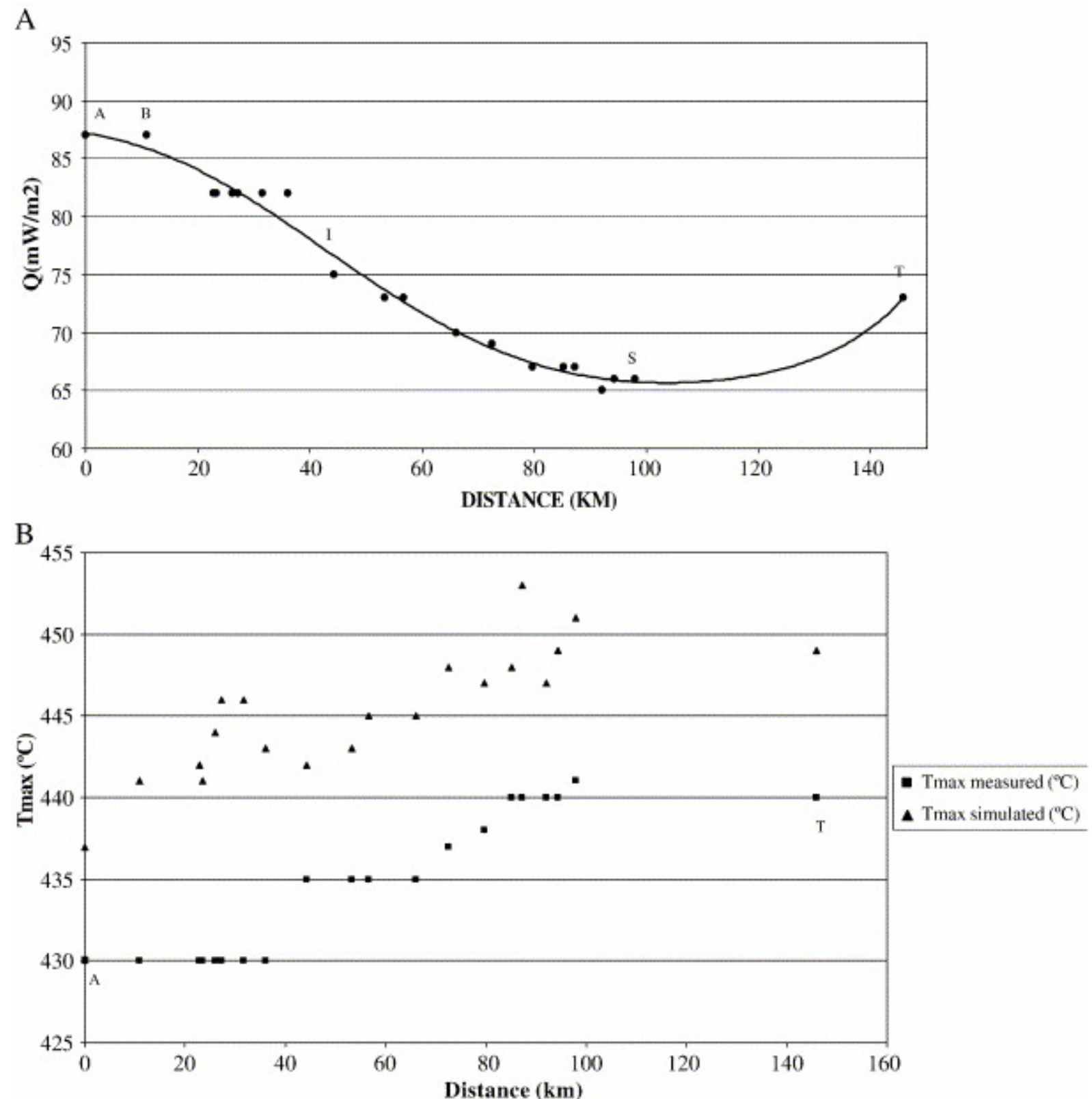

Fig. 3. (A) Heat flux simulated with TherMO'S. (B) Comparison between $T_{\max }$ data measured for the Hettangian sequence in the Paris basin to $T_{\max }$ values calculated with TherMO's for the calibration procedure. 
The study of the thermal properties of the stratigraphic horizons $\mathrm{H} 1$ and $\mathrm{H} 2$ permits to characterize the deposition of the Hettangian minor transgressive cycle. The evolution of the thermal gradients and conductivities obey to the burial of the sedimentary basin all along the cross-section. We have not included in our calculations considerations dealing with thermal relaxation. We can see, from the results obtained for the liassic sequences in the Rambouillet well (Fig. 4), that the thermal parameters are affected by the variation of the burial rate of the stratigraphic horizons.

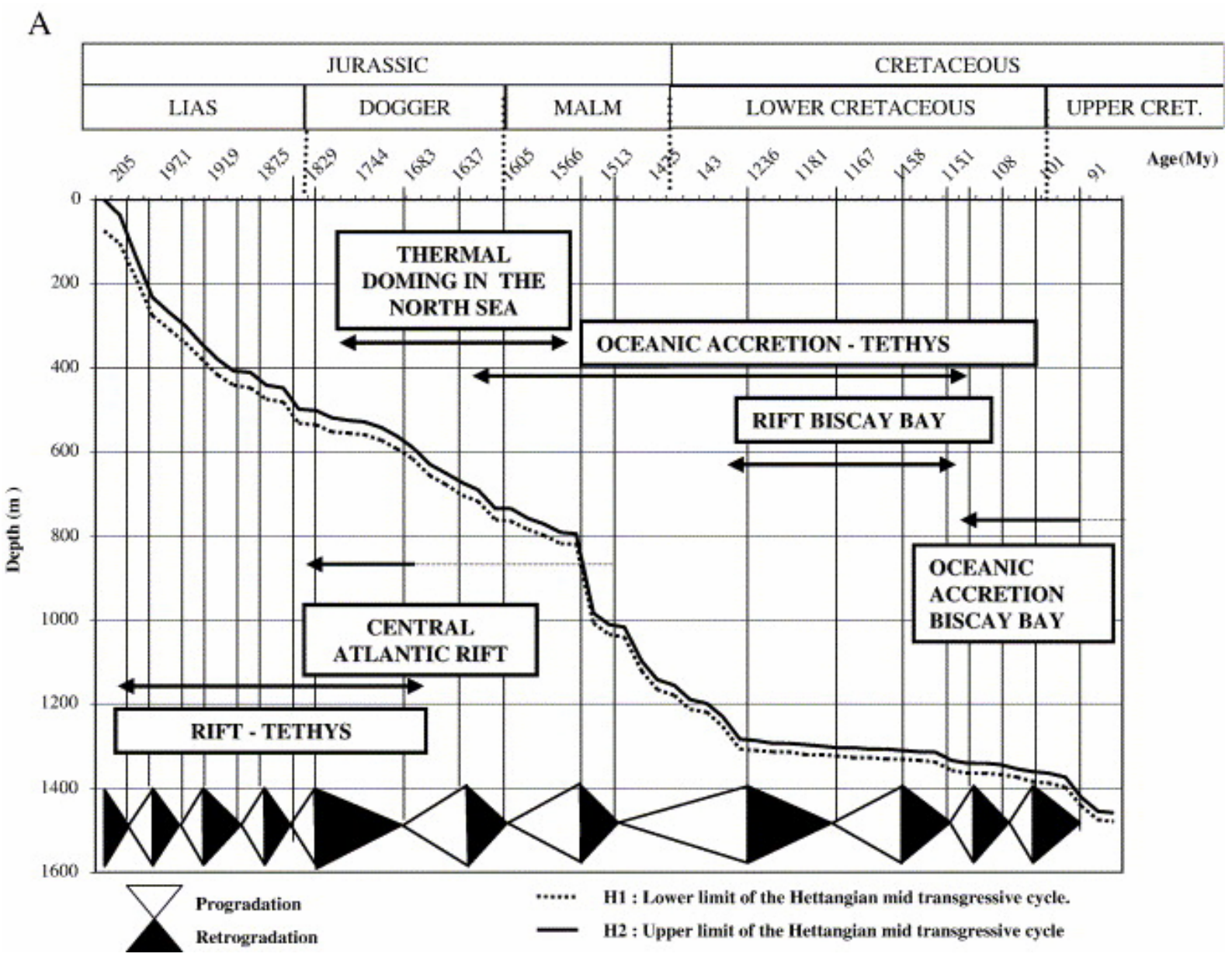


B

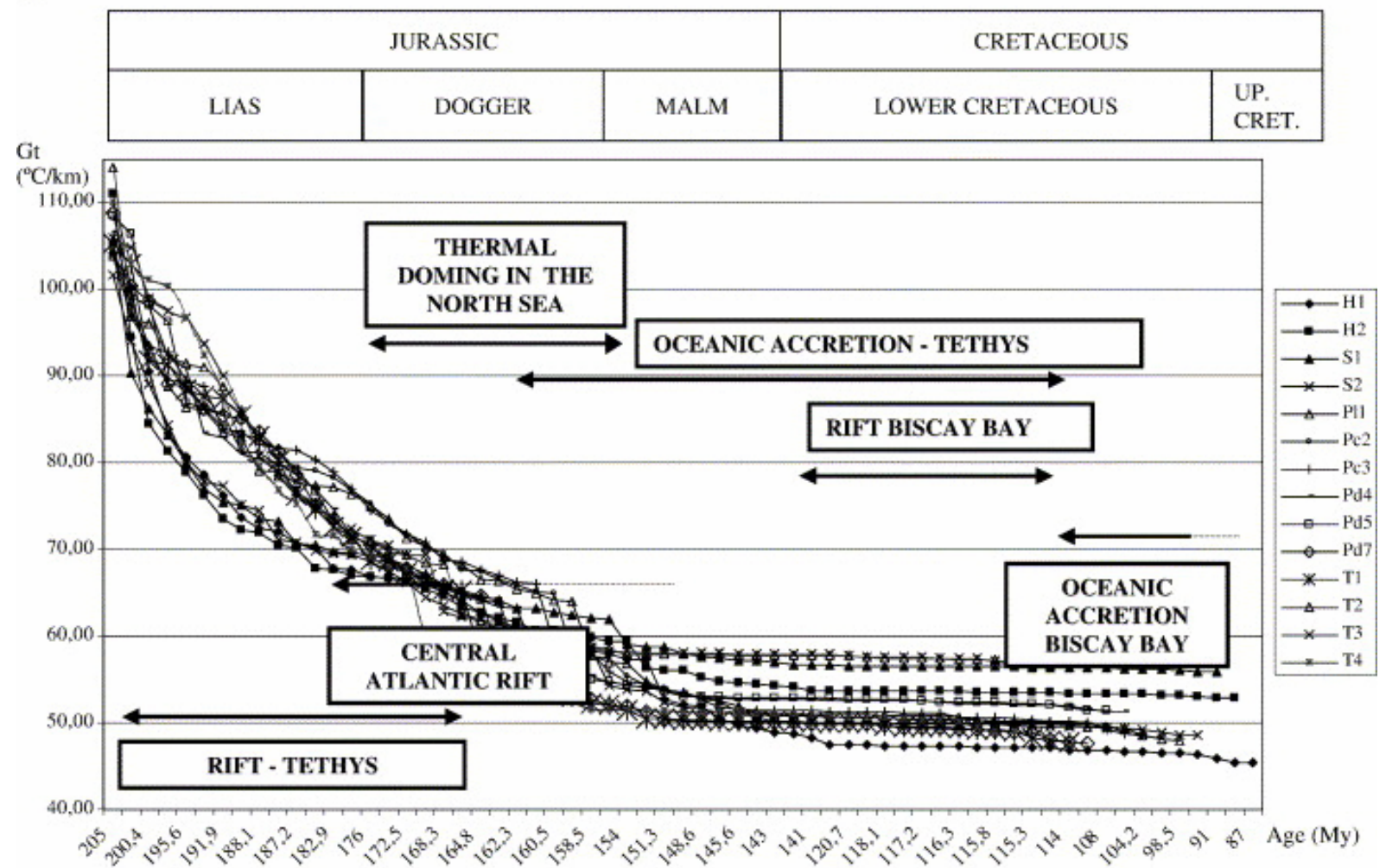

Fig. 4. (A) Simulation of the burial history for the Hettangian's sequences at the Rambouillet Well and geodynamic events associated. H1 is the lower limit of the Hettangian mid transgressive cycle; H2 is the upper limit of the Hettangian mid transgressive cycle and the lower limit of the Hettangian regressive cycle. (B) Simulation of the evolution of the palaeo thermal gradient Gt for the Liassic horizons at the Rambouillet Well. $\mathrm{H} 1, \ldots, \mathrm{T} 4$ are isochrons' name for remarkables surfaces. In particularly, those surfaces delimit mid-transgressive and regressive cycle. $\mathrm{H} 1$ is the lower limit of the Hettangian mid transgressive cycle; $\mathrm{H} 2$ is the the lower limit of the Hettangian mid regressive cycle; S1 is the lower limit of the Sinemurian mid-transgressive cycle; S2 is the lower limit of the Sinemurian mid-regressive cycle; P11 is the lower limit of the Pliensbachian mid-transgressive cycle; Pd4 is the lower limit of the Pliensbachian mid-regressive cycle; Pd7 is the lower limit of the Toarcian mid transgressive cycle; $\mathrm{T} 2$ is the lower limit of the Toarcian mid regressive cycle.

During Malm, the sudden decrease of the thermal gradients values observed is different according to the horizon considered. For the horizon H1, the thermal gradient decrease is $5.2 \times 10^{-3}{ }^{\circ} \mathrm{C} / \mathrm{m}$ whereas it is $3.3 \times 10^{-3}{ }^{\circ} \mathrm{C} / \mathrm{m}$ for the horizon $\mathrm{H} 2$. Thermal gradients values range from $100{ }^{\circ} \mathrm{C} / \mathrm{km}$ (at $205 \mathrm{My}$ ) to $57.33^{\circ} \mathrm{C} / \mathrm{km}$ (at $154 \mathrm{My}$ ) for $\mathrm{H} 1$ and from $111^{\circ} \mathrm{C} / \mathrm{km}$ (at $205 \mathrm{My}$ ) to $59.43{ }^{\circ} \mathrm{C} / \mathrm{km}$ (at $154 \mathrm{My}$ ) for $\mathrm{H} 2$. From the Malm stage, the thermal gradients decrease more slowly. Those results confirm that during past times, the thermal gradient recorded by Mesozoic sediments might have been hotter than during present days.

At $87 \mathrm{My}$, the thermal gradient for the Rambouillet well varies from 45 to $57{ }^{\circ} \mathrm{C} / \mathrm{km}$ according to the sequences considered. The mean thermal gradient calculated for $87 \mathrm{my}$ is 50.4 ${ }^{\circ} \mathrm{C} / \mathrm{km}$, a result in the range of values for thermal gradients obtained from previous studies on the Paris basin. Gaulier and Burrus (1994) published thermal gradients for liassic units ranging from 55 to $65^{\circ} \mathrm{C} / \mathrm{km}$. Consequently, it was also very interesting to note for the results here presented that the mean thermal gradient computed for each horizons from 205 to $87 \mathrm{My}$ ranged between 58.33 and $67.03{ }^{\circ} \mathrm{C} / \mathrm{km}$ (see Table 3 ). 
Table 3. : Numerical mean thermal gradient values calculated for each liassic horizons for the Rambouillet well

\begin{tabular}{|l|l|}
\hline Isochron & Mean value/isochron $\left({ }^{\circ} \mathbf{C} / \mathbf{k m}\right)$ \\
\hline H1 & 58.33 \\
\hline H2 & 61.38 \\
\hline S1 & 63.67 \\
\hline S2 & 59.64 \\
\hline P11 & 62.73 \\
\hline Pc2 & 63.16 \\
\hline Pc3 & 63.63 \\
\hline Pd4 & 63.27 \\
\hline Pd5 & 63.78 \\
\hline Pd7 & 61.97 \\
\hline T1 & 61.87 \\
\hline T2 & 67.03 \\
\hline T3 & 67.50 \\
\hline T4 & 62.81 \\
\hline & \\
\hline
\end{tabular}

$\mathrm{H} 1, \ldots, \mathrm{T} 4$ are isochrons' name for remarkables surfaces. In particular, those surfaces delimit mid-transgressive and regressive cycle. $\mathrm{H} 1$ is the lower limit of the Hettangian mid-transgressive cycle; $\mathrm{H} 2$ is the the lower limit of the Hettangian mid-regressive cycle; S1 is the lower limit of the Sinemurian mid transgressive cycle; S2 is the lower limit of the Sinemurian mid regressive cycle; P11 is the lower limit of the Pliensbachian mid transgressive cycle; Pd4 is the lower limit of the Pliensbachian mid regressive cycle; $\mathrm{Pd} 7$ is the lower limit of the Toarcian mid transgressive cycle; T2 is the lower limit of the Toarcian mid regressive cycle. The mean thermal gradient value for all liassic horizons is $62.91\left({ }^{\circ} \mathrm{C} / \mathrm{km}\right.$ and the mean thermal gradient value at 87 My for all liassic horizons is $50.59\left({ }^{\circ} \mathrm{C} / \mathrm{km}\right)$.

\section{Discussion}

The thermal history recorded by the Mesozoic sediments may be linked to (1) the geodynamic context and (2) the syn-sedimentary tectonic. Literature on the isotopic dating of burial based on illitization (Clauer et al., 1995) suggests that the Triassic was probably affected by a hydrothermal event. Geochemical analyses on clay minerals indicate different diagenetic events characterized by unusually warm thermal regimes at about $190 \mathrm{My}, 150 \mathrm{My}$ and 80 My (Liewig et al., 1987, Guilhaumou and Gaulier, 1991 and Spötl et al., 1996).

Since Triassic, sedimentary sequences recorded several phases of acceleration-deceleration of the subsidence. These episodes were linked to major geodynamic events affecting the West European plate (Guillocheau, 1991 and Prijac et al., 2000). Prijac et al. (2000) analysed the tectonic subsidence of the Paris basin as result from the decay of a thermal anomaly due to the collapse of the Variscan belt. For that purpose, they computed the thermal evolution of the lithosphere by considering the Plate and the Chablis model. Curves of large scale bulk subsidence in the Paris Basin (Prijac et al., 2000) show a long term component reflecting 
lithosphere cooling on which a shorter trend reflects the changes in the tectonic stresses. The long-term variation is exponential (Brunet and Le Pichon, 1982) and reflects the cooling rate after the Hercynian orogeny. Forward modeling indicates that subsidence rate is by evidence the fastest during the first 40 My immediately after the end of the orogeny (230 My), with about $600 \mathrm{~m}$ in amplitude. During the period in which we observe anomalous rates (190-140 My) the bulk subsidence is about $400 \mathrm{~m}$. It slows down to about $400 \mathrm{~m}$ in the next $100 \mathrm{My}$ (Prijac et al., 2000). The observed subsidence values during the anomalous period of time (190-140 My) are in deficit by about $150 \mathrm{~m}$ compared to the bulk subsidence rate. It documents a slower tectonic subsidence, evidencing, either a decrease in the heat conduction loss by the lithosphere or by a stiffer crustal response. The amplitude in time of the anomaly, appears too short compared to the time wavelength of lithospheric thermal loss. In consequence, a tectonic cause should be considered that varies in time the subsidence of the Paris Basin.

Gable (1984) pointed out a relationship could be suggested for explaining the origin of thermal anomalies characterized by high heat flows measured in the Paris Basin from geophysical methods and possible geological structures such as granitic massif (Armorican massif) or the upwarding of the Mohorovicic discontinuity and crustal thinning. Lefort and Agarwal, 1996 and Lefort and Agarwal, 2000 studied a possible correlation between heat flux and geophysical measurements (gravity and seismic data) for the Paris basin. This approach led them to identify Moho undulations under the basin. This method could be as well considered to establish the relationships between the lateral variation of the heat flows obtained from the modeling here presented and the geometry of the Paris Basin substratum (Cazes and Torreilles, 1988a and Cazes and Torreilles, 1988b).

Concerning the effect of the syn-sedimentary tectonic on the variation of the thermal parameters simulated, it is very interesting to point out the acceleration of the decreasing of thermal gradients for Liassic horizons during the Pliensbachian stage. At that particular period, the acceleration of burial may be related to the reactivation of the Seine-Loire fault and consequently have an impact on the thermal gradients evolution for that time.

\section{Conclusion}

Many of the thermal sedimentary basin models used in petroleum industry impose thermal gradients as a constant through geological time. The estimation of the thermal gradient is derived from the knowledge of the bottom borehole temperature.

TherMO's calculates thermal paleogradients from the simulated paleodepths and paleotemperatures. Taking into account the temporal variation of the thermal paleogradients associated to the burial history of each stratigraphic sequences (time scale: 1-5 My), we simulated the heat flux provided for the thermal cracking of the sedimentary organic matter by means of the conductivity and calibrated the results obtained with organic matter data reflecting its present state of maturity.

The heat flow through undisturbed sedimentary basins is usually either constant or decreasing as function of geological time (Tissot and Welte, 1984). The thermal history of the Paris basin is complex and has not been constant through geological time. It is only for simplicity of programming that the 1D TherMO's code considers a constant value for the heat flux. The reconstitution of the Paris basin thermal history led to different results depending on the 
method of study. But, on the whole, TherMO's calculation results are in good agreement with previous estimates.

The originality of the approach described in the present paper was to introduce the thermal gradient variation through geological time on basin modeling and examine the effect for the reconstitution of the Paris basin thermal history.

The knowledge of this thermal energy also calculated during the calibration procedure all along the burial history, at the stratigraphic resolution scale, may be a very interesting issue in the Petroleum Industry research programs. This method could help in the estimation of the geological timing of the hydrocarbons generation.

\section{Acknowledgments}

This paper is based on the thesis work of L. Amir at H. Poincaré University for the $\mathrm{PhD}$ degree. It was supported by the PNRH which is gratefully acknowledged. We also thank F. Malartre for suggestions that allowed us to improve the manuscript.

\section{References}

Allen and Allen, 1990 P.A. Allen and J. Allen, Basin Analysis: Principles and Applications, Blackwell Scientific Publications (1990).

Arrhenius, 1909 S. Arrhenius, Theorien der chemie, Akademische Verlagsgesellschaft m.b.H, Leipzig (1909), pp. 138-221.

Bessereau et al., 1995 G. Bessereau, F. Guillocheau and A.-Y. Huc, Source rock occurrence in a sequence stratigraphic framework: the example of the lias of the Paris Basin, AAPG Studies in Geology 40 (1995), pp. 670-685.

S. Bourquin and F. Guillocheau, Keuper stratigraphic cycles in the Paris Basin and comparison with cycles in other Peritethyan basins (German Basin and Bresse-Jura Basin), Sedimentary Geology 105 (1996), pp. 159-182.

Bourquin et al., 2002 S. Bourquin, C. Robin, F. Guillocheau and J.M. Gaulier, Threedimensional accommodation analysis of the Keuper of the Paris Basin: discrimination between tectonics, eustasy and sediment supply in the stratigraphic record, Marine and Petroleum Geology 19 (2002), pp. 469-498.

Bowen, 1966 R. Bowen, Paleotemperature analysis, Methods in Geochemistry and Geophysics vol. 2, Elsevier, Amsterdam (1966) 139 pp..

Brunet and Le Pichon, 1980 M.-F. Brunet and X. Le Pichon, Effet des variations eustatiques sur la subsidence dans le Bassin de Paris, Bulletin de la Société Géologique de France (7) XXII (1980) (4), pp. 631-637.

Brunet and Le Pichon, 1982 M.F. Brunet and X. Le Pichon, Subsidence of the Paris Basin, Journal of Geophysical Research 87 (1982) (B10), pp. 8547-8560. 
Cazes and Torreilles, 1988a In: M. Cazes and G. Torreilles, Editors, Etude de la croûte terrestre par sismique profonde-Profil Nord de la France-Structure Hercynienne vol. 1, Editions Technip, Paris (1988) 260 pp..

Cazes and Torreilles, 1988b In: M. Cazes and G. Torreilles, Editors, Planche hors texte. Etude de la croûte terrestre par sismique profonde-Profil Nord de la France-Structure Hercynienne vol. 2, Editions Technip, Paris (1988) 260 pp..

Clauer et al., 1995 N. Clauer, J.R. O'Neil and S. Furlan, Clay minerals as records of temperature conditions and duration of thermal anomalies in the Paris Basin, France, Clay Minerals 30 (1995), pp. 1-13.

Curnelle and Dubois, 1986 R. Curnelle and P. Dubois, Evolution mésozoïque des grands bassins sédimentaires français; bassins de Paris, d'Aquitaine et du Sud-Est, Bulletin de la Société Géologique de France 8 (1986) (II), pp. 529-546.

Demars, 1994 Demars, C., 1994. Evolution diagenetique, paleofluides et paleothermicite dans les reservoirs du Keuper et du Dogger du bassin de Paris. INPL Thesis, Nancy 1, Nancy. 394 pp.

Disnar, 1986 J.R. Disnar, Détermination de paléotemperatures maximales d'enfouissement de sédiments charbonneux a partir de données de pyrolyse, Comptes Rendus de l'Académie Paris, Série II 303 (1986), pp. 691-696.

Disnar, 1994 J.R. Disnar, Determination of maximum paleotemperatures of burial (MPTB) of sedimentary rocks from pyrolysis data on the associated organic matter: basic principles and practical application, Chemical Geology 118 (1994), pp. 289-299. Abstract

Disnar et al., 1996a J.R. Disnar, P. Le Strat, G. Farjanel and A. Fikri, Organic matter sedimentation in the northeast of the Paris Basin: consequences on the deposition of the lower Toarcian Black Shales, Chemical Geology 131 (1996), pp. 15-35.

Disnar et al., 1996b J.R. Disnar, P. Le Strat, G. Farjanel and A. Fikri, Sédimentation de la matière organique dans le nord-est du Bassin de Paris: conséquences sur le dépôt des argilites carbonées du Toarcien inférieur (Organic matter sedimentation in the northeast of the Paris Basin: consequences on the deposition of the lower toarcian black shales), Chemical Geology 131 (1996), pp. 15-35

Espitalie et al., 1987 J. Espitalie, F. Marquis, L. Sage and I. Barsony, Géochimie organique du bassin de Paris, Revue de l'Institut Français du Pétrole 42 (1987), pp. 271-302.

Gable, 1984 Gable, R., 1984. Acquisition et Interprétation des données géothermiques. These de Doctorat d'Etat, Pierre et Marie Curie University (Paris VI). France. 172 pp.

Gaulier and Burrus, 1994 J.M. Gaulier and J. Burrus, Modeling present and past thermal regimes in the paris basin: petroleum implications. In: A. Mascle, Editor, Hydrocarbon and Petroleum Geology of France, Springer-Verlag, Berlin (1994), pp. 61-73.

Guilhaumou and Gaulier, 1991 N. Guilhaumou and J.-M. Gaulier, Détermination de paléotempératures dans les roches mères du bassin de Paris: Etude d'inclusions fluides et 
implications pour l'histoire thermique du bassin, Comptes Rendus de l'Académie des Sciences de Paris 313 (1991) (II), pp. 773-780.

Guillocheau, 1991 F. Guillocheau, Mise en évidence de grands cycles transgressionrégression d'origine tectonique dans les sédiments mésozoïques du bassin de Paris, Comptes Rendus de l'Académie des Sciences de Paris 312 (1991) (II), pp. 1587-1593.

Guillocheau et al., 2000 F. Guillocheau, C. Robin, P. Allemand, S. Bourquin, N. Brault, G. Dromart, R. Friedenberg, J.P. Garcia, J.M. Gaulier, F. Gaumet, B. Grosdoy, F. Hanot, P. Le Strat, M. Mettraux, T. Nalpas, T. Prijac, C. Rogoillet, O. Serrano and G. Grandjean, MesoCenozoic geodynamic evolution of the Paris Basin: 3D stratigraphic constraints, Geodinamica Acta 13 (2000), pp. 189-245.

Jacquin and De Graciansky, 1997 T. Jacquin and P.C. De Graciansky, Major transgressiveregressive cycles: the stratigraphic signature of European basin development. In: P.C. De Graciansky, J. Hardenbol, T. Jacquin and P.R. Vail, Editors, Mesozoic and Cenozoic Sequence Stratigraphy of European Basin, Soc. Econ. Paleontol, Mineral. Spec. Publ. (1997).

Lafargue et al., 1998 E. Lafargue, F. Marquis and D. Pillot, Rock Eval 6 applications in hydrocarbon exploration, production, and soil contamination studies, Revue de l'Institut Français du Pétrole 53 (1998), pp. 421-437. Abstract-Compendex

Lefort and Agarwal, 1996 J.P. Lefort and B.N.P. Agarwal, Gravity evidence for an Alpine buckling of the crust beneath the Paris Basin, Tectonophysics 258 (1996), pp. 1-14.

Lefort and Agarwal, 2000 J.P. Lefort and B.N.P. Agarwal, Gravity and geomorphological evidence for a large crustal bulge cutting across Brittany (France): a tectonic response to the closure of the Bay of Biscay, Tectonophysics 323 (2000), pp. 149-162

Liewig et al., 1987 N. Liewig, J.-R. Mossmann and N. Clauer, Datation isotopique K-Ar d'argiles diagénétiques de réservoirs gréseux: mise en évidence d'anomalies thermiques du Lias inférieur en Europe nord-occidentale, Comptes Rendus de l'Académie des Sciences de Paris 304 (1987) (II), pp. 707-709.

Lucazeau and Vasseur, 1989 F. Lucazeau and G. Vasseur, Heat flow density data from France and surrounding margins, Tectonophysics 164 (1989), pp. 251-258. Abstract

Martinez et al., 2000 L. Martinez, I. Suarez-Ruiz, J. Duplay, M. Guzman Vega, A.M. Saenz de Santa Maria, J. Benedet and A. Gutierrez Rodriguez, Thermal evolution of the maceral composition, reflectance and gas potential of coals: application of a numerical model 7th Latin American Congress on Organic Geochemistry, October 18-21, Iguaçu, Brazil (2000), pp. 159-162.

Megnien, 1980 C. Megnien, Tectogenese du Bassin de Paris: étapes de l'évolution du bassin, Bulletin de la Société Géologique de France XXII (1980) (7), pp. 669-680.

Odin, 1994 G.S. Odin, Geological time scale, Comptes Rendus de l'Académie des Sciences de Paris 318 (1994), pp. 59-71. 
Poulet and Espitalie, 1987 M. Poulet and J. Espitalie, Hydrocarbon migration in the Paris Basin. In: B. Doligez, Editor, Migration of Hydrocarbons in Sedimentary Basins Proceedings of the 2nd IFP Exploration Research Conference, June 15-19, Editions Technip, Carcans (1987), pp. 131-171.

Prijac et al., 2000 C. Prijac, M.P. Doin, J.M. Gaulier and F. Guillocheau, Subsidence of the Paris Basin and its bearing on the late Variscan lithosphere evolution: a comparison between Plate and Chablis models, Tectonophysics 323 (2000), pp. 1-38.

Robin, 1997 Robin, C., 1997. Mesure stratigraphique de la deformation: Application a l'evolution jurassique du bassin de Paris. Doctorat thesis, Rennes 1, Rennes. 293 p.

Robin et al., 1996 C. Robin, F. Guillocheau and J.-M. Gaulier, Mesure des signaux eustatiques et tectoniques au sein de l'enregistrement d'un bassin intracratonique. Application au Lias du Bassin de Paris, Comptes Rendus de l'Académie des Sciences de Paris 322 (1996) (II), pp. 1079-1086. Abstract-GEOBASE

Spötl et al., 1996 C. Spötl, R.H. Worden and F. Walgenwitz, Clay minerals as records of temperature conditions and duration of thermal anomalies in the Paris basin, France: discussion, Clay Minerals 31 (1996), pp. 203-208.

Tissot and Welte, 1984 B.P. Tissot and D.H. Welte, Petroleum Formation and Occurrence, Springer-Verlag, Berlin (1984).

Ungerer et al., 1991 P. Ungerer, J. Burrus, B. Doligez, P.Y. Chenet and F. Bessis, Evaluation des bassins par modélisation intégrée en deux dimensions des transferts thermiques, de l'écoulement des fluides, de la genèse et de la migration des hydrocarbures, Revue de l'Institut Français du Pétrole 46 (1991), pp. 3-36.

Vasseur et al., 1995 G. Vasseur, F. Brigaud and L. Demongodin, Thermal conductivity estimation in sedimentary basins, Tectonophysics 244 (1995), pp. 167-174.

Yukler and Kokesh, 1984 M.A. Yukler and F. Kokesh, A review of models used in petroleum ressource estimation and organic geochemistry, Advances in Petroleum Geochemistry 1 (1984), pp. 69-113. 